\title{
IL-23 production is regulated via an MSK1/2 - CREB dependent signalling pathway downstream of Toll like receptors.
}

Kirsty F. Houslay, Manuel van Gijsel-Bonnello, Tsvetana Petrova, Shaista Naqvi, J. Simon

C. Arthur*

Division of Cell Signalling and Immunology, College of Life Sciences, Wellcome Trust Building, University of Dundee, Dundee, DD1 5EH.

*Corresponding Author:

Simon Arthur

e-mail j.s.c.arthur@dundee.ac.uk

tel $+44(0) 1382384003$

fax $+44(0) 1382381098$

Running title

MSK1/2 - CREB dependent regulation of IL-23

Keywords MAPK; CREB; TLR; interleukin; macrophage 


\begin{abstract}
IL-23 is an IL-12 family cytokine that is important in promoting Th17 responses and has been strongly linked to autoimmunity and psoriasis. It is a heterodimeric cytokine made up of a p19 subunit unique to IL-23 and a p40 subunit that is shared with IL-12. We show here that in response to LPS, the induction of IL-23p19 mRNA is regulated by a MSK1/2 - CREB dependent pathway downstream of ERK1/2 and p38 $\alpha$ MAPK. Knockout of MSK1/2 resulted in a decrease in both IL-23p19 mRNA transcription and IL-23 secretion in GM-CSF differentiated bone marrow cells. Similar effects were seen when the MSK1/2 phosphorylation site in CREB was mutated to alanine. Stimulation with PGE2 promotes the nuclear localisation of CRTC3, a co-activator for CREB. In combination with LPS, PGE2 promoted IL-23p19 mRNA transcription and this was blocked by knockdown of CRTC3. Imiquimod induced skin inflammation in mice has been used as a model for psoriasis and is dependent on IL-23. While MSK1/2 knockout reduced the induction of IL-23 in vivo following i.p. injection of LPS, the knockout mice were not protected from Imiquimod induced skin inflammation. MSK1/2 knockout did not reduce the induction of IL-17 producing $\gamma \delta \mathrm{T}$ cells following Imiquimod treatment, although MSK1/2 knockout did reduce the levels of these cells in mice receiving a control cream. The lack of protection in the Imiquimod model may be due to the known anti-inflammatory roles or MSKs, such as its contribution to the induction of IL-10.
\end{abstract}

\title{
Introduction
}

Innate immune cells such as macrophages and dendritic cells respond to pathogens via Pattern Recognition Receptors (PRRs) that recognise specific Pathogen Associated Molecular Patterns (PAMPs). Toll like receptors (TLRs) comprise one such family of PRRs that play an important role in the host response to viral, microbial and fungal pathogens in both mice and humans. TLRs activate a number of intracellular signalling pathways, including Mitogen activated protein kinase (MAPK) cascades and the NFKB and IFR transcription factors[1-4]. Together these pathways induce the production of a range of pro-inflammatory molecules like cytokines and chemokines that help co-ordinate the inflammatory response to the pathogen. While inflammation is a key component of the host response, excessive inflammation can cause tissue damage and in extreme cases can lead to organ injury and mortality. It is therefore critical that inflammation is precisely regulated and a number of feedback pathways and anti-inflammatory mechanisms are deployed in order to achieve the right balance [5-7]. Paradoxically the same signalling pathways that promote inflammation are also involved in activating anti-inflammatory processes. One example of this is the $\mathrm{p} 38 \alpha$ MAPK cascade, which promotes the production of the pro-inflammatory cytokine TNF by macrophages [8-10] and p38 inhibitors have been shown to reduce inflammation in mouse models of endotoxic shock $[11,12]$. p $38 \alpha$ however also serves to limit inflammation. For example, p38 $\alpha$ phosphorylates and inhibits the TAB/TAK complex, which activates both NFKB and MAPK pathways following TLR activation [13]. p38 $\alpha$ also helps promote the induction of DUSP1, a phosphatase that limits p38 and JNK activation [14-17], and the antiinflammatory cytokine IL-10 [14].

Both IL-10 and DUSP1 can be regulated at transcriptional level in macrophages [15-19], and p38 $\alpha$ has been described to regulate these genes via the activation of Mitogen and Stress Activated Protein Kinase (MSK) 1 and 2. MSK1 and 2 are nuclear protein kinases that can be activated downstream of either the ERK1/2 or p38 $\alpha$ MAPK cascades [1]. For stimuli, such as TLR agonists, that activate both ERK1/2 and p38 $\alpha$, combined inhibition of both pathways is required to completely block MSK activation [20, 21]. A number of substrates have been 
described for MSKs including the transcription factors CREB and ATF1 and the chromatin protein histone H3 [22, 23]. Through phosphorylation of these substrates MSKs can regulate the induction of its target genes downstream of MAPK signalling. Both IL-10 and DUSP1 are CREB regulated, and CREB has been shown to be required for the maximal induction of these genes downstream of TLR agonists in macrophages [14, 21, 24-26]. MSKs phosphorylate CREB on Ser133 resulting in activation of its transcriptional activity [22, 27]. In addition to phosphorylation on Ser133, CREB can also be regulated by the CREB regulated transcription coactivator (CRTC) proteins. CRTCs can be phosphorylated by members of the Salt Inducible Kinase (SIK) family and these results in 14-3-3 binding and retention of the CRTC proteins in the cytoplasm [28]. Inhibition of SIKs allows the dephosphorylation of CRTC and their translocation to the nucleus where they can bind to CREB [28-30]. In macrophages, prostaglandin E2 (PGE2) has been shown to inhibit SIK mediated CRTC phosphorylation and promote CRTC3 localisation to the nucleus where it can help activate IL-10 transcription [29]. As a result, stimulation of macrophages with PGE2 and the TLR4 agonist LPS results in a greater production of IL-10 than stimulation with LPS alone.

In contrast to IL-10 knockout mice, which develop colitis [31], MSK1/2 double knockout mice are viable and do not develop any of the spontaneous phenotypes associated with IL-10 loss [22]. MSK1/2 knockout mice do however show an increased sensitivity to LPS induced endotoxic shock and produce higher levels of TNF, IL-6, IL-12 and IFN $\beta$ in response to LPS than wild type mice $[21,25,32]$. One of the plausible explanations for the differences in the phenotypes of MSK1/2 and IL-10 knockout mice is the possibility that MSKs and CREB may also regulate some pro-inflammatory genes in macrophages in addition to their described anti-inflammatory targets. In this study, we show that MSKs and CREB regulate the induction of IL-23p19 subunit downstream of TLR agonists. IL-23 is a member of the IL12 family and has well established roles in the maintenance of Th17 cells and the development of autoimmunity [33-35]. Thus, like its upstream activator $\mathrm{p} 38 \alpha$, MSK1/2 can also induce both pro- and anti-inflammatory cytokines in innate immune cells.

\section{Results \\ IL-23p19 mRNA induction is regulated via MSK - CREB pathway in macrophages}

We have previously shown that PGE2 and LPS promote IL-10 induction via a CREB dependent mechanism in macrophages [29]. To identify other genes that might be regulated in a similar manner, we re-examined microarray data comparing bone marrow derived macrophages (BMDMs) stimulated with either LPS, PGE2 or a combination of LPS and PGE2 for $1 \mathrm{~h}$. 139 genes were identified as being upregulated more than 4-fold by LPS alone. 18 of these genes were upregulated further 2-fold when a combination of LPS and PGE2 was used (Fig 1A); of these IllO, IL-6, Ptgs2, NR4A1, NR4A3, Trem1, Gjal and IL1rn have previously been reported as CREB or MSK regulated genes [36-42]. In addition, Il23a was identified in this list. Il23a encodes the p19 subunit of IL-23, a pro-inflammatory cytokine implicated in the maintenance of IL-17 producing T cells [43, 44]. Il23a was selected for further study as $I l 23 a$ knockout in mice has been shown to be protective in a range of autoimmune models including experimental autoimmune encephalomyelitis (EAE), arthritis and imiquimod-induced skin inflammation [44-46]. To confirm the microarray data, IL23p19 mRNA was analysed by qPCR in independent samples. As expected, this showed a similar pattern of IL-23p19 mRNA regulation to the array data (Fig 1B).

To determine if IL-23p19 mRNA induction was regulated via an MSK - CREB dependent 
pathway, a combination of small molecule inhibitors and mouse genetics was used.

Following LPS stimulation of macrophages, the ERK1/2 and p38 MAPK pathways activate MSK1/2 which phosphorylate CREB at S133 [21]. Inhibition of the ERK1/2 pathway with PD184352 or the p38 pathways with VX745 reduced IL-23p19 mRNA induction, while a combination of both inhibitors further reduced IL-23p19 mRNA induction in response to LPS. The induction of IL-23p19 mRNA was also decreased by the MSK inhibitor SB747651A (Fig 1C). To confirm these results, Bone Marrow-derived Macrophages (BMDMs) were prepared from wild type, MSK1/2 double knockout and CREB-S133A knockin mice (Fig 1D). The induction of IL-23p19 mRNA was decreased in both the MSK1/2 knockout and CREB S133A knockin BMDMs relative to wild type cells in response to LPS. PGE2 did not induce IL-23p19 mRNA in any of the genotypes, demonstrating a role for an MSK CREB dependent pathway in LPS induced IL-23p19 mRNA induction. MSK1/2 knockout or CREB S133A knockin BMDMs showed reduced IL-23p19 mRNA induction relative to wild type cells in response to a combination of LPS and PGE2. A combination of LPS and PGE2 gave a stronger induction of IL-23p19 mRNA than LPS alone for all 3 genotypes, suggesting that the effect of PGE2 is independent of MSK1/2 and CREB S133 phosphorylation (Fig 1D). Changes in mRNA levels can be due to changes in either transcription or mRNA stability. Changes in the level of the primary RNA transcript for a gene can provide a better readout for changes in transcription than analysis of mRNA levels. We therefore looked at the effect of MSK1/2 knockout on IL-23p19 transcript levels following LPS stimulation. As for the mRNA, MSK1/2 knockout reduced IL-23p19 primary transcript levels (Fig 1E). To determine if MSKs affected IL-23p19 mRNA stability, BMDMs were treated with LPS for $1 \mathrm{~h}$ and then actinomycin D was added to block further transcription. The loss of IL-23p19 mRNA was then measured over time showing no effect on IL-23p19 mRNA stability in MSK1/2 knockout compared to wildtype BMDMs (Fig 1F). Together these results would indicate that MSK1/2 regulate IL-23p19 mRNA transcription via CREB phosphorylation. PGE2 activates the cAMP-PKA pathway in macrophages, which is able to promote the nuclear localisation of the CRTC family of CREB co-activator proteins [29]. We have previously shown that CRTC3 is important for the regulation of IL-10 in macrophages using siRNA [29]. We therefore analysed the effect on IL-23p19 mRNA induction in these experiments. Knockdown of CRTC1 or 2 did not affect IL-23p19 mRNA induction. In contrast, while CRTC3 knockdown did not affect LPS-induced IL-23p19 mRNA induction, it did block the increase seen when PGE2 was added in combination with LPS (Fig 2A). Successful knockdown of the respective CRTC isoforms was confirmed by qPCR (Fig 2B). CRTC3 is phosphorylated by a member of the SIK family causing the CRTC3 to be retained in the cytoplasm. Activation of PKA downstream of PGE2 allows PKA to phosphorylate SIKs and block their ability to phosphorylate CRTC3 [29]. In agreement with this, treatment with MRT67307, which inhibits all three SIK isoforms, mimicked the effect of PGE2 on LPS stimulated IL-23p19 mRNA induction (Fig 2C).

\section{MSKs regulate the production and secretion of IL-23}

IL-23 is a heterodimer of IL-23p19 and IL-12p40 subunits. While BMDMs upregulate both p19 and p40 mRNA in response to LPS they do not secrete measurable amount of IL-23 [47]. In contrast, bone marrow cells differentiated in GM-CSF (GM-BMCs), which gives rise to heterogenous population of macrophages and dendritic cells [48], do secrete detectable levels of IL-23 in response to TLR stimulation [47]. We first confirmed that MSKs were activated in GM-BMCs in response to LPS (Fig 3A). TLR stimulation activated ERK1/2 and p38, as judged by phosphorylation on the TXY motifs. In line with this LPS stimulated the phosphorylation of MSK1 on Thr581, a site that correlates with MSK1 activation [20]. LPS 
stimulation also resulted in the phosphorylation of the MSK substrate CREB, and this phosphorylation was absent in GM-BMCs from MSK1/2 knockout mice (Fig 3A). LPS increased the levels of IL-23p19 mRNA, as well as the mRNA for IL-12p40 and IL-12p35 (Fig 3B). As in MSK1/ 2 knockout GM-BMCs, the induction of IL-23p19 mRNA was reduced relative to wild type GM-BMCs (Fig 3B). The levels of IL-12p40 were not affected by MSK1/2 knockout at most of the time points analysed, while IL-12p35 mRNA was increased at later time points (Fig 3C and D). This increase in IL-12p35 may be due to the ability of MSKs to regulate IL-10 induction in GM-BMCs [25], as IL-10 can set up a negative feedback loop to repress IL-12p35 induction. Consistent with this, MSK1/2 knockout reduced IL-10 secretion in response to LPS and increased IL-12p70 secretion (Supplementary Fig 1A). Similar to the findings in BMDMs, PGE2 in combination with LPS resulted in a higher induction of IL-23p19 mRNA than LPS alone (Fig 3E and F). Relative to wild type GM-BMCs, both MSK1/2 knockout and CREB S133A knockin reduced the induction of IL-23p19 mRNA in response to either LPS or LPS and PGE2 in combination. LPS and PGE2 in combination gave a higher induction of IL-23p19 mRNA than LPS alone in all 3 genotypes, suggesting that the effect of PGE2 did not require CREB S133 phosphorylation (Fig 3E and F).

In line with the reduction in IL-23p19 mRNA, MSK1/2 knockout reduced the secretion of IL23 following LPS stimulation (Fig $3 \mathrm{G}$ and $\mathrm{H}$ ). As has previously been reported, treatment of BMDMs with GM-CSF resulted in the detectable secretion of IL-23 following LPS stimulation (Supplementary Fig 1B, [47]). Under these conditions MSK1/2 also resulted in a reduced secretion of IL-23 relative to with type GM-BMCs (Supplementary Fig 1B). In agreement with the data for MSK1/2 knockouts, CREB S133A knockin also reduced IL-23 secretion in response to LPS in GM-BMCs (Fig 3I). Treatment with LPS and PGE2 together resulted in a modest increase in IL-12 production relative to IL-23 alone (Fig $3 \mathrm{H}$ and I). Surprisingly, in response to LPS and PGE2 neither MSK1/2 knockout or CREB S133A knockin reduced IL-23 secretion relative to wild type cells (Fig H and I), despite IL-23 mRNA being decreased (Fig E and F). One potential reason is that IL-23 is a heterodimer of IL-23p19 and IL-12p40. In response to LPS alone, IL-12p40 production may not be limiting. However, while PGE2 promotes IL-23p19 production, it strongly inhibits the production of IL-12p40 via both IL-10 dependent and independent mechanisms (Fig 3J).

As MSK1/2 knockout decreased IL-23 secretion from isolated GM-BMCs, we next determined if MSKs were required for optimal IL-23 production in vivo. Mice were given an i.p. injection of either LPS or PBS and IL-23 levels measured in the serum. Wild type mice produced IL-23 in response to LPS. In line with the experiments in GM-BMCs, MSK1/2 knockout mice produced significantly less IL-23 following LPS injection than wild type animals (Fig 4)

\section{Effect of MSK1/2 knockout on in vivo IL-23 production and imiquimod induced skin inflammation.}

In mice, treatment of the skin with Aldara, a cream containing the TLR7 agonist imiquimod, induces a psoriasis like skin inflammation. Knockout of the IL-23p19 subunit has been shown to protect mice from inflammation in this model [45]. The ears of wild type and MSK1/2 knockout mice were treated with Aldara or Oilatum (a control cream that does not contain imiquimod) for 7 days after which mice were untreated for 4 days to allow inflammation to resolve. Ear thickness was measured throughout this period as measurement of inflammation. Thickening was observed in both wild type and MSK1/2 knockout mice treated with Aldara, and in both cases this started to resolve once treatment was stopped. No differences were however observed between the two genotypes in the changes in ear 
thickness (Fig 5A). Analysis of IL-17 levels in biopsies taken on day 5 and day 11 showed that IL-17A and IL-17F levels were induced in the ear by Aldara treatment, however again there were no significant differences between the wild type and MSK1/2 knockout mice (Fig 5B and C). In agreement with this, IL17A and F mRNA levels in ear biopsies were not affected by MSK1/2 knockout (Fig 5D and E). Increased levels of IL-23p19 mRNA were detected following Aldara treatment in wild type mice, however in contrast to the previous results in GM-BMCs, the levels were not affected by MSK1/2 knockout (Fig 5F) while IL12 p40 mRNA levels were also not affected (Fig 5G).

In addition to promoting inflammation in the ear, Aldara also has systematic effects in the mice. Mice treated with Aldara for 6 days showed an increase in spleen size as well as increased numbers of neutrophils, Ly6C+ve and Ly6C-ve monocytes in the spleen (Fig 6A to E, Supplementary Fig 2). The numbers of neutrophils and monocytes in the spleens of Aldara treated mice was not affected by knockout of MSK1 and 2. There was however a slight decrease in the numbers of neutrophils in MSK1/2 knockout mice compared to wild type animals receiving the control Oilatum cream. Previous studies have shown that IL-23 is involved in the induction of IL-17 producing $\gamma \delta$-T cells following Aldara treatment $[49,50]$. The numbers of $\gamma \delta$ T cells were similar between wild type and MSK1/2 knockout mice (Supplementary Fig 3). Aldara increased the proportion of $\gamma \delta$-T cells in spleen able to make IL-17 on ex vivo stimulation with PMA, however this was not affected by MSK1/2 knockout (Fig 6F). In mice treated with Oilatum the percentage of T cells able to produce IL-17 was lower in MSK1/2 knockout mice relative to wild types (Fig 6F), and a similar result was found in the lymph nodes (Supplementary Fig 3).

\section{Discussion}

In this study, we show that in BMDMs and GM-BMCs, the induction of IL-23p19 mRNA downstream of TLR4 requires the activation of an MSK1/2 - CREB dependent pathway (Fig 7). MSKs are activated via the ERK1/2 and p38 MAPK pathways [20, 22]. Therefore, the role for MSK1/ 2 in regulating IL-23 production is consistent with the findings that ERK1/2 and/or p38 $\alpha$ pathways are involved in this process [50-52]. For example, inhibition of ERK1/2 or p38 was reported to reduce the induction of a IL-23p19 luciferase reporter in macrophages [53] while inhibition of ERK1/2 and or p38 reduced IL-23p19 induction in Langerhans cells, epithelial cells and colorectal cancer cells.

MSK1/2 knockout has been found to sensitise mice to LPS induced endotoxic shock [21]. This is partly due to a reduction in the production of the anti-inflammatory cytokine IL-10, accompanied by an increased production of a number of pro-inflammatory cytokines including TNF, IL-6 IL-12 and IFN $\beta$ [21, 26, 32]. The ability of MSKs to promote IL-23p19 induction is however unlikely to be dependent on its role in controlling IL-10 production, as IL-10 represses IL-23p19 mRNA induction in response to LPS ([53] Supplementary Fig 1C). Although the majority of previously described MSK targets in macrophages, such as IL-10, IL-1ra, DUSP1 and TTP, all have anti-inflammatory roles, MSK1/2 knockout mice do not show overt signs of spontaneous inflammatory pathologies. One reason for this may be that the anti-inflammatory role of MSKs is cell type restricted to a subset of immune cells; for example while MSK1/2 regulates LPS induced IL-10 production in macrophages it is not required for IL-10 secretion by LPS stimulated B cells [21, 54]. An additional possibility is that MSKs have some pro-inflammatory roles in addition to their known anti-inflammatory functions. The regulation of IL-23 production by MSK1/2 would be one such proinflammatory function. In this respect, MSKs over all effects may have similarities to those of $\mathrm{p} 38 \alpha$. While $\mathrm{p} 38 \alpha$ activation was originally thought of as pro-inflammatory signal, further work has shown that $\mathrm{p} 38 \alpha$ is able to activate both pro and anti-inflammatory pathways in innate immune cells $[13,14] . \mathrm{p} 38 \alpha$ activates the kinases MK2 and 3 in addition to MSK1 and 
2. Given that MK2/3 are important in the production of TNF, while MSK1/2 regulate IL-10 it has been suggested that substrate selective $\mathrm{p} 38 \alpha$ inhibitors or MK2/3 inhibitors may retain the ability to block pro-inflammatory cytokines while sparing IL-10 production [55]. This has not proved true - we show here that MSKs are required for IL-23 production and other studies have found that MK2/3 are required for IL-10 production in addition to regulating TNF $[55,56]$. Thus both MSKs and MKs play both pro and anti-inflammatory roles downstream of $\mathrm{p} 38 \alpha$.

While LPS stimulates CREB phosphorylation via MSK1/ 2, PGE2 activates PKA which can also phosphorylate CREB on S133 in macrophages [29]. Despite this, PGE2 alone did not induce a strong induction of IL-23p19 mRNA. This may be due to a requirement for additional LPS activated transcription factor binding sites on the IL-23p19 promoter that may be not be activated by PGE2 alone. For example, several putative NFKB sites have been identified and mutation of the two proximal sites has been shown to reduce transcription from the IL-23p19 promoter. Consistent with this, knockout of the c-Rel NFkB subunit reduces LPS stimulated IL-23p19 mRNA induction in both macrophages and dendritic cells [57, 58]. An ability of PGE2 to enhance LPS and $\beta$-glucan stimulated IL-23 production in dendritic cells has been noted previously [59-61]. While CREB is required for the effects of PGE2 on IL-23 [59, 62], CREB phosphorylation is not critical and instead the effect is mediated via a SIK - CRTC3 dependent pathway (Fig 1-2). The ability of PGE2 to increase TLR induced IL-23p19 mRNA transcription is in contrast to its inhibitory effects on the induction of IL$12 \mathrm{p} 40$, which is a second component in the IL-23 heterodimer. While the effects of PGE2 on IL-23p19 transcription are clear, its effects on IL-23 secretion are more complex as IL-12p40 may become limiting in the formation of the IL-23 heterodimer. While in dendritic cells PGE2 generally enhances IL-23 secretion, in human monocytes PGE2 inhibits IL-23 secretion as the IL-12p40 subunit is limiting [63]. This may explain why MSK1/2 knockout affected IL-23p19 mRNA induction following LPS and PGE2 stimulation when it did not have a significant effect of IL-23 secretion (Fig 3).

IL-23 is important for the pathogenesis of psoriasis and IL-23 neutralising antibodies have proved successful in the clinic for psoriasis treatment [64-66]. Increased phosphorylation of both MSK1 and CREB have been reported in psoriatic skin lesions, suggesting potential role for MSKs in the disease[67-69]. Imiquimod induced skin inflammation has been used as a mouse model for psoriasis [65] and knockout of IL-23p19 is protective in this model [45]. While MSK1/2 reduced IL-23 production from cultured GM-BMCs and following i.p. injection of LPS in mice, it did not have a major impact on imiquimod induced skin inflammation. This may be due to the complex effects of MSKs on innate immunity. Although MSK1/2 knockout reduces IL-23 production in response to LPS, it also reduces IL10 production while promoting the production of TNF, IL-6, IL-12, INF $\beta$ and PGE2 by TLR stimulated macrophages. Related to this, knockout of IL-10 mice results in increased inflammation in imiquimod induced skin inflammation as well as elevated levels of IL-23p19 mRNA [70]. Interestingly, while MSK1/2 knockout did not affect the numbers of IL-17 producing $\gamma \delta$ T cells in the spleens of Aldara treated mice, they were reduced in Oilatum treated animals. This could suggest that the Aldara treatment saturates the response and a difference is only seen when the potential inflammatory stimulus is much weaker. In summary, we show that IL-23 induction in cultured cells can be regulated via an MSK CREB dependent pathways downstream of TLR activation. Despite this MSK1/2 knockout did not prevent the development of imiquimod induced skin inflammation, a process known to be dependent of IL-23, suggesting a more complex effect of MSK1/2 knockout in vivo. 
bioRxiv preprint doi: https://doi.org/10.1101/2020.07.07.189142; this version posted July 7, 2020. The copyright holder for this preprint (which was not certified by peer review) is the author/funder, who has granted bioRxiv a license to display the preprint in perpetuity. It is made available under aCC-BY-NC-ND 4.0 International license. 


\section{Methods \\ Mice}

MSK1 and MSK2 knockout and CREB S133A knockin mice have been described previously $[22,71]$. MSK1/2 mice were backcrossed onto C57B1/6 (>18 generations). CREB mice had been backcrossed to C57B1/6 for a least 12 generations. Non breeding mice were housed in same-sex groups, in individually ventilated sterile cages and were given standard diet R\&M1 (SDS, Special Diets Services). Animals were maintained in rooms with controlled $12 \square \mathrm{h} / 12 \square \mathrm{h} \mathrm{light} /$ dark cycle, $21 \square^{\circ} \mathrm{C}$ temperature, and relative humidity of $45-65 \%$. All the work was performed under a UK Home Office project license in accordance with UK and EU regulations and subject to local ethical review by the University of Dundee Ethical Review Committee.

To measure in vivo cytokine induction, mice were given an i.p. injection of either PBS or 2 $\mathrm{mg} / \mathrm{kg}$ LPS (Sigma (E. coli 055:B5)) dissolved in PBS. After the indicated time, mice were culled and blood taken by cardiac puncture.

\section{Array datasets}

A microarray data set on unstimulated BMDMs and BMDMs treated with LPS, PGE2 or LPS $+\mathrm{PGE}_{2}$ for $1 \mathrm{~h}$ using Affymetrix mouse gene 1.1 ST arrays has been described previously [29] and has the accession number GSE41833.

\section{Cell culture}

BMDMs and GM-BMCs were cultured as described [72]. Briefly, bone marrow was flushed in PBS from the femur and tibia of mice. Cells were cultured in bacterial grade plastic for 7 days at $37^{\circ} \mathrm{C}, 5 \% \mathrm{CO}_{2}$. Cells were then detached using Versene (Gibco), re-plated on tissue culture plastic in the appropriate media and used within $48 \mathrm{~h}$. Primary cells were cultured in DMEM supplemented with $10 \%$ heat inactivated FBS, $2 \mathrm{mM}$ L-glutamine, $100 \mathrm{U} / \mathrm{ml}$ penicillin $\mathrm{G}, 100 \mu \mathrm{g} / \mathrm{ml}$ streptomycin and $0.25 \mu \mathrm{g} / \mathrm{ml}$ amphotericin. BMDMs were cultured in $5 \mathrm{ng} / \mathrm{ml} \mathrm{M-CSF}$ while GM-BMCs were cultured in $10 \mathrm{ng} / \mathrm{ml} \mathrm{GM-CSF}$. Where indicated cells were treated with $2 \mu \mathrm{M}$ MRT67307, $2 \mu \mathrm{M}$ PD184352, $1 \mu \mathrm{M}$ VX-745 of $10 \mu \mathrm{M}$ SB-74651A for $1 \mathrm{~h}$ before stimulation. Cells were stimulated with either $100 \mathrm{ng} / \mathrm{ml}$ LPS (E. coli 055:B5) or $10 \mu \mathrm{M}$ PGE2 for the times indicated in the legends.

For CRTC knockdown experiments, siRNA was transfected into primary BMDMs using the Lonza Amaxa Optimized Mouse Macrophage Nucleofection system (catalog number VPA1009). Smartpool siGENOME siRNAs were purchased from Thermo-Dharmacon. These experiments gave efficient knockdown of CRTC1, 2 and 3 as reported previously [29].

\section{qPCR}

Following stimulation cells were lysed and total RNA isolated using Nucleospin RNA purification columns according to the manufactures protocol (Macherey-Nagel). 0.5 to $1 \mu \mathrm{g}$ of total RNA was reverse transcribed using BioRad iScript, qPCR was then carried out using SyberGreen based detection methods (Takara Biosciences). Fold induction relative to the wild type unstimulated sample was calculated as described using 18s and/or GAPDH as reference gene [36]. Primer sequences for 18s, GAPDH, CRTCs, IL-12p40 and IL-12p70 have been described previously [29, 72]. IL-23p19 mRNA was detected using the primers ATCCAGTGTGAAGATGGTTGTGAC and TTCTAGTAGGGAGGTGTGAAGTTG while IL-23p19 primary transcript was detected with the primers AATGTGCCCCGTATCCAGTG and R: GGCTTAGTGGTACCTGGCTG. The primers for IL-17A were CTCCAGAAGGCCCTCAGACTAC and AGCTTTCCCTCCGCATTGACACAG and IL17F were CTGGAGGATAACACTGTGAGAGT and TGCTGAATGGCGACGGAGTTC. 


\section{Cytokine measurements.}

Cytokines were measured from serum or cell culture media as described. For measurement of cytokine levels in inflamed skin, tissue from an ear notch ( $2 \mathrm{~mm}$ diameter) was homogenised in protein lysis buffer $(50 \mathrm{mM}$ Tris $\mathrm{HCl}(\mathrm{pH} 8), 150 \mathrm{mM} \mathrm{NaCl}, 0.5 \%$ Sodium Deoxycholate, $1 \% \mathrm{NP}-40,0.1 \%$ SDS, $1 \mu \mathrm{g} / \mathrm{ml}$ Leupetin, $1 \mu \mathrm{g} / \mathrm{ml}$ Aprotinin, $1 \mathrm{mM}$ PMSF) using $5 \mathrm{~mm}$ Stainless Beads and TissueLyser II (frequency: 30/sec, duration 2 x $30 \mathrm{sec}$ ) (Qiagen, Hilden, Germany). IL-23 was measured using either a mouse IL-23 ELISA (R\&D) or Luminex based method from BioRad. IL-12p40, Il-12p70, IL-17A, IL-17F and IL-10 were measured using a Luminex based method using Bioplex reagents from BioRad.

\section{Immunoblotting.}

Cells were lysed directly into SDS sample buffer and aliquots run on $10 \%$ polyacrylamide gels using standard methods. Proteins were transferred onto nitrocellulose membranes, and specific proteins were detected by immunoblotting. Antibodies against phospho-ERK1/2, phospho-p38, total ERK1/2, total p38 $\alpha$, phospho-Ser133 CREB (which also recognizes ATF1 phosphorylated on Ser63) and phospho-Thr581 MSK1 were from Cell Signalling Technology. The total MSK1 antibody was generated in-house [22]. HRP-conjugated secondary antibodies were from Pierce (Cheshire, U.K.), and detection was performed using the ECL reagent from Amersham Biosciences (Buckinghamshire, U.K.).

\section{Imiquimod induced skin inflammation}

Mice were treated with Aldara cream (5\% Imiquimod, Meda SD, Solna, Sweden) or Oilatum (control soft cream, Glaxo Operation UK Ltd, Durham, UK). All experiments were carried out blind to the genotype of the animals. Aldara and Oilatum were applied for 7 consecutive days; equally on dorsal and ventral surface of right and left ears with a total dose of 40mg total per mouse per day. Animals were maintained on a $12 \mathrm{~h}$ light $/ 12 \mathrm{~h}$ dark cycle, and cream was applied between 3 and $4 \mathrm{~h}$ into the light cycle. Once daily, prior to application, ear thickness was measured using a Mitutoyo 7301 dial thickness gauge (Mitutoyo, Kawasaki, Japan). Mice were sacrificed 4 hours or 3 days after last treatment as indicated in the figure legends, and ear samples were taken for further analysis. If required, an intermediate $2 \mathrm{~mm}$ diameter ear biopsy was taken during the experiment. Samples for mRNA expression level and protein analysis were snap frozen in liquid nitrogen and stored at -80 " C until further use.

\section{Flow cytometry}

Spleens were isolated from mice and single cell suspensions prepared via passing through a $100 \mu \mathrm{m}$ filter. After RBC lysis cells were stained with $0.5 \mu \mathrm{g} / \mathrm{ml}$ DAPI and live cells were counted on BD FACSVerse ${ }^{\mathrm{TM}}$. For flow cytometry analysis, $1 \times 10^{6}$ cells were blocked for 20 min at $4^{\circ} \mathrm{C}$ with FcR antibody (purified anti-CD16/32; BD Pharmingen) diluted (1:50) in PBS containing $1 \%$ Bovine serum albumin. For neutrophils and monocytes characterisation, the cells were stained for $20 \mathrm{~min}$ at $4^{\circ} \mathrm{C}$ with the anti-CD45 (BV510), anti-NK1.1 (APC/Cy7), anti-CD11b (PE/Cy7), anti-Gr-1 (PerCp/Cy5.5), anti-CD115 (APC), anti-Ly-6C, anti-CX3CR1(PE), anti-I-A/I-E (MHCII) (AlexaFluor700), anti-CD11c (PE/Dazzle)/ To measure intracellular levels of IL-17, cells were seeded at density of $1 \times 10^{6}$ in $1 \mathrm{~mL}$ complete RPMI media (RPMI-1640 medium with $10 \%$ heat-inactivated FBS, $50 \mathrm{U} / \mathrm{ml}$ penicillin-streptomycin, 10mM HEPES buffer, $1 \mathrm{mM}$ sodium pyruvate, $50 \mu \mathrm{M} 2$ mercaptoethanol, $2 \mathrm{mM}$ L-Glutamine, $0.1 \mathrm{mM}$ Non-essential amino acids) and stimulated with $50 \mathrm{ng} / \mathrm{ml} \mathrm{PMA}$ and $1 \mu \mathrm{g} / \mathrm{ml}$ ionomycin plus brefeldin A $(5 \mu \mathrm{g} / \mathrm{ml})$ for 4 hours. 
Following stimulation cells were washed with FACS buffer (PBS + 1\% BSA), fixed using fixation buffer (eBioscience) for $20 \mathrm{~min}$ at $+4^{\circ} \mathrm{C}$, washed with FACS buffer, permeabilised with $1 \mathrm{x}$ permeabilisation buffer (eBioscience) for $20 \mathrm{~min}$ at $+4^{\circ} \mathrm{C}$, After washing in FACS buffer cells were incubated with 1:50 Fc block made up in 1x permeabilisation buffer for $20 \mathrm{~min}$ at $+4^{\circ} \mathrm{C}$, washed with FACS buffer and incubated with antibodies (1:100 TCR- $\beta$ FITC, 1:100 TCR- $\gamma \delta$ APC, 1:200 IL-17 PE, and 1:200 CD4 PerCp/Cy5.5) made up in 1x permeabilisation buffer for $30 \mathrm{~min}$ at $+4^{\circ} \mathrm{C}$. Stained cells were washed with FACS buffer and data acquired on a BD LSR Fortessa ${ }^{\mathrm{TM}}$ and further analysed using FlowJo software.

\section{Author contributions}

KFH, MGB, TP and SN carried out experimental work, all authors contributed to data analysis and preparation of the manuscript.

\section{Funding and additional information}

The work was supported by grants from the Medical Research Council and Versus Arthritis (JSCA)

\section{Conflict of interest}

The authors have no conflict of interest. 
References

1 Arthur, J. S. and Ley, S. C. (2013) Mitogen-activated protein kinases in innate immunity. Nat Rev Immunol. 13, 679-692

2 Cohen, P. (2014) The TLR and IL-1 signalling network at a glance. J Cell Sci. 127, 23832390

3 Kawai, T. and Akira, S. (2011) Toll-like receptors and their crosstalk with other innate receptors in infection and immunity. Immunity. 34, 637-650

4 O'Neill, L. A., Golenbock, D. and Bowie, A. G. (2013) The history of Toll-like receptors - redefining innate immunity. Nat Rev Immunol. 13, 453-460

5 O'Neill, L. A. (2008) When signalling pathways collide: positive and negative regulation of toll-like receptor signal transduction. Immunity. 29, 12-20

6 Murray, P. J. (2006) Understanding and exploiting the endogenous interleukin10/STAT3-mediated anti-inflammatory response. Curr Opin Pharmacol. 6, 379-386

7 Clark, K. (2014) Protein kinase networks that limit TLR signalling. Biochem Soc Trans. 42, $11-24$

8 Ronkina, N., Kotlyarov, A., Dittrich-Breiholz, O., Kracht, M., Hitti, E., Milarski, K., Askew, R., Marusic, S., Lin, L. L., Gaestel, M. and Telliez, J. B. (2007) The mitogen-activated protein kinase (MAPK)-activated protein kinases MK2 and MK3 cooperate in stimulation of tumor necrosis factor biosynthesis and stabilization of p38 MAPK. Mol Cell Biol. 27, 170-181 9 Lee, J. C., Laydon, J. T., McDonnell, P. C., Gallagher, T. F., Kumar, S., Green, D., McNulty, D., Blumenthal, M. J., Heys, J. R., Landvatter, S. W., Strickler, J. E., McLaughlin, M. M., Siemens, I. R., Fisher, S. M., Livi, G. P., White, J. R., Adams, J. L. and Young, P. R. (1994) A protein kinase involved in the regulation of inflammatory cytokine biosynthesis. Nature.

372, 739-746

10 Kang, Y. J., Chen, J., Otsuka, M., Mols, J., Ren, S., Wang, Y. and Han, J. (2008) Macrophage deletion of p38alpha partially impairs lipopolysaccharide-induced cellular activation. J Immunol. 180, 5075-5082

11 O'Keefe, S. J., Mudgett, J. S., Cupo, S., Parsons, J. N., Chartrain, N. A., Fitzgerald, C., Chen, S. L., Lowitz, K., Rasa, C., Visco, D., Luell, S., Carballo-Jane, E., Owens, K. and Zaller, D. M. (2007) Chemical genetics define the roles of p38alpha and p38beta in acute and chronic inflammation. J Biol Chem. 282, 34663-34671

12 Badger, A. M., Bradbeer, J. N., Votta, B., Lee, J. C., Adams, J. L. and Griswold, D. E. (1996) Pharmacological profile of SB 203580, a selective inhibitor of cytokine suppressive binding protein/p38 kinase, in animal models of arthritis, bone resorption, endotoxin shock and immune function. J Pharmacol Exp Ther. 279, 1453-1461

13 Cheung, P. C., Campbell, D. G., Nebreda, A. R. and Cohen, P. (2003) Feedback control of the protein kinase TAK1 by SAPK2a/p38alpha. EMBO J. 22, 5793-5805

14 Kim, C., Sano, Y., Todorova, K., Carlson, B. A., Arpa, L., Celada, A., Lawrence, T., Otsu, K., Brissette, J. L., Arthur, J. S. and Park, J. M. (2008) The kinase p38 alpha serves cell typespecific inflammatory functions in skin injury and coordinates pro- and anti-inflammatory gene expression. Nat Immunol. 9, 1019-1027

15 Abraham, S. M. and Clark, A. R. (2006) Dual-specificity phosphatase 1: a critical regulator of innate immune responses. Biochem Soc Trans. 34, 1018-1023

16 Lang, R., Hammer, M. and Mages, J. (2006) DUSP meet immunology: dual specificity MAPK phosphatases in control of the inflammatory response. J Immunol. 177, 7497-7504 
17 Hu, J. H., Chen, T., Zhuang, Z. H., Kong, L., Yu, M. C., Liu, Y., Zang, J. W. and Ge, B. X. (2007) Feedback control of MKP-1 expression by p38. Cell Signal. 19, 393-400

18 Gabrysova, L., Howes, A., Saraiva, M. and O'Garra, A. (2014) The regulation of IL-10 expression. Curr Top Microbiol Immunol. 380, 157-190

19 Mackenzie, K. F., Pattison, M. J. and Arthur, J. S. (2014) Transcriptional regulation of IL-10 and its cell-specific role in vivo. Crit Rev Immunol. 34, 315-345

20 McCoy, C. E., Campbell, D. G., Deak, M., Bloomberg, G. B. and Arthur, J. S. (2005) MSK1 activity is controlled by multiple phosphorylation sites. Biochem J. 387, 507-517

21 Ananieva, O., Darragh, J., Johansen, C., Carr, J. M., Mcllrath, J., Park, J. M., Wingate, A., Monk, C. E., Toth, R., Santos, S. G., Iversen, L. and Arthur, J. S. (2008) The kinases MSK1 and MSK2 act as negative regulators of Toll-like receptor signalling. Nat Immunol. 9, 10281036

22 Wiggin, G. R., Soloaga, A., Foster, J. M., Murray-Tait, V., Cohen, P. and Arthur, J. S. (2002) MSK1 and MSK2 are required for the mitogen- and stress-induced phosphorylation of CREB and ATF1 in fibroblasts. Mol Cell Biol. 22, 2871-2881

23 Soloaga, A., Thomson, S., Wiggin, G. R., Rampersaud, N., Dyson, M. H., Hazzalin, C. A., Mahadevan, L. C. and Arthur, J. S. (2003) MSK2 and MSK1 mediate the mitogen- and stress-induced phosphorylation of histone H3 and HMG-14. EMBO J. 22, 2788-2797

24 Wen, A. Y., Sakamoto, K. M. and Miller, L. S. (2010) The role of the transcription factor CREB in immune function. J Immunol. 185, 6413-6419

25 Elcombe, S. E., Naqvi, S., Van Den Bosch, M. W., Mackenzie, K. F., Cianfanelli, F., Brown, G. D. and Arthur, J. S. (2013) Dectin-1 regulates IL-10 production via a MSK1/2 and CREB dependent pathway and promotes the induction of regulatory macrophage markers. PLoS One. 8, e60086

26 Danne, C., Ryzhakov, G., Martinez-Lopez, M., Ilott, N. E., Franchini, F., Cuskin, F., Lowe, E. C., Bullers, S. J., Arthur, J. S. C. and Powrie, F. (2017) A Large Polysaccharide Produced by Helicobacter hepaticus Induces an Anti-inflammatory Gene Signature in Macrophages. Cell Host Microbe. 22, 733-745 e735

27 Naqvi, S., Martin, K. J. and Arthur, J. S. (2014) CREB phosphorylation at Ser133 regulates transcription via distinct mechanisms downstream of CAMP and MAPK signalling. Biochem J. 458, 469-479

28 Screaton, R. A., Conkright, M. D., Katoh, Y., Best, J. L., Canettieri, G., Jeffries, S., Guzman, E., Niessen, S., Yates, J. R., 3rd, Takemori, H., Okamoto, M. and Montminy, M. (2004) The CREB coactivator TORC2 functions as a calcium- and cAMP-sensitive coincidence detector. Cell. 119, 61-74

29 Mackenzie, K. F., Clark, K., Naqvi, S., McGuire, V. A., Noehren, G., Kristariyanto, Y., van den Bosch, M., Mudaliar, M., McCarthy, P. C., Pattison, M. J., Pedrioli, P. G., Barton, G. J., Toth, R., Prescott, A. and Arthur, J. S. (2013) PGE(2) induces macrophage IL-10 production and a regulatory-like phenotype via a protein kinase A-SIK-CRTC3 pathway. J Immunol. 190, 565-577

30 Clark, K., MacKenzie, K. F., Petkevicius, K., Kristariyanto, Y., Zhang, J., Choi, H. G., Peggie, M., Plater, L., Pedrioli, P. G., Mclver, E., Gray, N. S., Arthur, J. S. and Cohen, P. (2012) Phosphorylation of CRTC3 by the salt-inducible kinases controls the interconversion of classically activated and regulatory macrophages. Proc Natl Acad Sci U S A. 109, 1698616991

31 Kuhn, R., Lohler, J., Rennick, D., Rajewsky, K. and Muller, W. (1993) Interleukin-10deficient mice develop chronic enterocolitis. Cell. 75, 263-274 
32 McGuire, V. A., Rosner, D., Ananieva, O., Ross, E. A., Elcombe, S. E., Naqvi, S., van den Bosch, M. M. W., Monk, C. E., Ruiz-Zorrilla Diez, T., Clark, A. R. and Arthur, J. S. C. (2017) Beta Interferon Production Is Regulated by p38 Mitogen-Activated Protein Kinase in Macrophages via both MSK1/2- and Tristetraprolin-Dependent Pathways. Mol Cell Biol. 37 33 Croxford, A. L., Mair, F. and Becher, B. (2012) IL-23: one cytokine in control of autoimmunity. Eur J Immunol. 42, 2263-2273

34 Teng, M. W., Bowman, E. P., McElwee, J. J., Smyth, M. J., Casanova, J. L., Cooper, A. M. and Cua, D. J. (2015) IL-12 and IL-23 cytokines: from discovery to targeted therapies for immune-mediated inflammatory diseases. Nat Med. 21, 719-729

35 Gaffen, S. L., Jain, R., Garg, A. V. and Cua, D. J. (2014) The IL-23-IL-17 immune axis: from mechanisms to therapeutic testing. Nat Rev Immunol. 14, 585-600

36 Darragh, J., Ananieva, O., Courtney, A., Elcombe, S. and Arthur, J. S. (2010) MSK1 regulates the transcription of IL-1ra in response to TLR activation in macrophages. Biochem J. 425, 595-602

37 Darragh, J., Soloaga, A., Beardmore, V. A., Wingate, A. D., Wiggin, G. R., Peggie, M. and Arthur, J. S. (2005) MSKs are required for the transcription of the nuclear orphan receptors Nur77, Nurr1 and Nor1 downstream of MAPK signalling. Biochem J. 390, 749-759 38 MacKenzie, K. F., Van Den Bosch, M. W., Naqvi, S., Elcombe, S. E., McGuire, V. A., Reith, A. D., Blackshear, P. J., Dean, J. L. and Arthur, J. S. (2013) MSK1 and MSK2 inhibit lipopolysaccharide-induced prostaglandin production via an interleukin-10 feedback loop. Mol Cell Biol. 33, 1456-1467

39 Spooren, A., Kooijman, R., Lintermans, B., Van Craenenbroeck, K., Vermeulen, L., Haegeman, G. and Gerlo, S. (2010) Cooperation of NFkappaB and CREB to induce synergistic IL-6 expression in astrocytes. Cell Signal. 22, 871-881

40 Etienne, S., Bourdoulous, S., Strosberg, A. D. and Couraud, P. O. (1999) MHC class II engagement in brain endothelial cells induces protein kinase A-dependent IL-6 secretion and phosphorylation of CAMP response element-binding protein. J Immunol. 163, 36363641

41 Yun, S. P., Park, S. S., Ryu, J. M., Park, J. H., Kim, M. O., Lee, J. H. and Han, H. J. (2012) Mechanism of PKA-dependent and lipid-raft independent stimulation of Connexin43 expression by oxytoxin in mouse embryonic stem cells. Mol Endocrinol. 26, 1144-1157 42 Hosoda, H., Tamura, H., Kida, S. and Nagaoka, I. (2011) Transcriptional regulation of mouse TREM-1 gene in RAW264.7 macrophage-like cells. Life Sci. 89, 115-122

43 Korn, T., Bettelli, E., Oukka, M. and Kuchroo, V. K. (2009) IL-17 and Th17 Cells. Annu Rev Immunol. 27, 485-517

44 Cua, D. J., Sherlock, J., Chen, Y., Murphy, C. A., Joyce, B., Seymour, B., Lucian, L., To, W., Kwan, S., Churakova, T., Zurawski, S., Wiekowski, M., Lira, S. A., Gorman, D., Kastelein, R. A. and Sedgwick, J. D. (2003) Interleukin-23 rather than interleukin-12 is the critical cytokine for autoimmune inflammation of the brain. Nature. 421, 744-748

45 van der Fits, L., Mourits, S., Voerman, J. S., Kant, M., Boon, L., Laman, J. D., Cornelissen, F., Mus, A. M., Florencia, E., Prens, E. P. and Lubberts, E. (2009) Imiquimodinduced psoriasis-like skin inflammation in mice is mediated via the IL-23/IL-17 axis. J Immunol. 182, 5836-5845

46 Adamopoulos, I. E., Tessmer, M., Chao, C. C., Adda, S., Gorman, D., Petro, M., Chou, C. C., Pierce, R. H., Yao, W., Lane, N. E., Laface, D. and Bowman, E. P. (2011) IL-23 is critical for induction of arthritis, osteoclast formation, and maintenance of bone mass. J Immunol. 187, 951-959 
47 Fleetwood, A. J., Lawrence, T., Hamilton, J. A. and Cook, A. D. (2007) Granulocytemacrophage colony-stimulating factor (CSF) and macrophage CSF-dependent macrophage phenotypes display differences in cytokine profiles and transcription factor activities: implications for CSF blockade in inflammation. J Immunol. 178, 5245-5252

48 Helft, J., Bottcher, J., Chakravarty, P., Zelenay, S., Huotari, J., Schraml, B. U., Goubau, D. and Reis e Sousa, C. (2015) GM-CSF Mouse Bone Marrow Cultures Comprise a Heterogeneous Population of CD11C(+)MHCII(+) Macrophages and Dendritic Cells. Immunity. 42, 1197-1211

49 Cai, Y., Shen, X., Ding, C., Qi, C., Li, K., Li, X., Jala, V. R., Zhang, H. G., Wang, T., Zheng, J. and Yan, J. (2011) Pivotal role of dermal IL-17-producing gammadelta T cells in skin inflammation. Immunity. 35, 596-610

50 Zheng, T., Zhao, W., Li, H., Xiao, S., Hu, R., Han, M., Liu, H., Liu, Y., Otsu, K., Liu, X. and Huang, G. (2018) p38alpha signalling in Langerhans cells promotes the development of IL17-producing T cells and psoriasiform skin inflammation. Sci Signal. 11

51 Lim, K. S., Yong, Z. W. E., Wang, H., Tan, T. Z., Huang, R. Y., Yamamoto, D., Inaki, N., Hazawa, M., Wong, R. W., Oshima, H., Oshima, M., Ito, Y. and Voon, D. C. (2020) Inflammatory and mitogenic signals drive interleukin 23 subunit alpha (IL23A) secretion independent of IL12B in intestinal epithelial cells. J Biol Chem. 295, 6387-6400

52 Scholz, G. M., Heath, J. E., Walsh, K. A. and Reynolds, E. C. (2018) MEK-ERK signalling diametrically controls the stimulation of IL-23p19 and EBI3 expression in epithelial cells by IL-36gamma. Immunol Cell Biol. 96, 646-655

53 Liu, W., Ouyang, X., Yang, J., Liu, J., Li, Q., Gu, Y., Fukata, M., Lin, T., He, J. C., Abreu, M., Unkeless, J. C., Mayer, L. and Xiong, H. (2009) AP-1 activated by toll-like receptors regulates expression of IL-23 p19. J Biol Chem. 284, 24006-24016

54 Sutavani, R. V., Phair, I. R., Barker, R., McFarlane, A., Shpiro, N., Lang, S., Woodland, A. and Arthur, J. S. C. (2018) Differential control of Toll-like receptor 4-induced interleukin10 induction in macrophages and B cells reveals a role for p90 ribosomal S6 kinases. J Biol Chem. 293, 2302-2317

55 Shah, N. G., Tulapurkar, M. E., Ramarathnam, A., Brophy, A., Martinez, R., 3rd, Hom, K., Hodges, T., Samadani, R., Singh, I. S., Mackerell, A. D., Jr., Shapiro, P. and Hasday, J. D. (2017) Novel Noncatalytic Substrate-Selective p38alpha-Specific MAPK Inhibitors with Endothelial-Stabilizing and Anti-Inflammatory Activity. J Immunol. 198, 3296-3306

56 Ehlting, C., Rex, J., Albrecht, U., Deenen, R., Tiedje, C., Kohrer, K., Sawodny, O., Gaestel, M., Haussinger, D. and Bode, J. G. (2019) Cooperative and distinct functions of MK2 and MK3 in the regulation of the macrophage transcriptional response to lipopolysaccharide. Sci Rep. 9, 11021

57 Mise-Omata, S., Kuroda, E., Niikura, J., Yamashita, U., Obata, Y. and Doi, T. S. (2007) A proximal kappaB site in the IL-23 p19 promoter is responsible for RelA- and c-Reldependent transcription. J Immunol. 179, 6596-6603

58 Carmody, R. J., Ruan, Q., Liou, H. C. and Chen, Y. H. (2007) Essential roles of c-Rel in TLR-induced IL-23 p19 gene expression in dendritic cells. J Immunol. 178, 186-191

59 Kocieda, V. P., Adhikary, S., Emig, F., Yen, J. H., Toscano, M. G. and Ganea, D. (2012) Prostaglandin E2-induced IL-23p19 subunit is regulated by CAMP-responsive elementbinding protein and C/AATT enhancer-binding protein beta in bone marrow-derived dendritic cells. J Biol Chem. 287, 36922-36935 
60 Khayrullina, T., Yen, J. H., Jing, H. and Ganea, D. (2008) In vitro differentiation of dendritic cells in the presence of prostaglandin E2 alters the IL-12/IL-23 balance and promotes differentiation of Th17 cells. J Immunol. 181, 721-735

61 Gagliardi, M. C., Teloni, R., Mariotti, S., Bromuro, C., Chiani, P., Romagnoli, G., Giannoni, F., Torosantucci, A. and Nisini, R. (2010) Endogenous PGE2 promotes the induction of human Th17 responses by fungal ss-glucan. J Leukoc Biol. 88, 947-954 62 Ma, X., Aoki, T. and Narumiya, S. (2016) Prostaglandin E2-EP4 signalling persistently amplifies CD40-mediated induction of IL-23 p19 expression through canonical and noncanonical NF-kappaB pathways. Cell Mol Immunol. 13, 240-250

63 Kalim, K. W. and Groettrup, M. (2013) Prostaglandin E2 inhibits IL-23 and IL-12 production by human monocytes through down-regulation of their common p40 subunit. Mol Immunol. 53, 274-282

64 Blauvelt, A. and Chiricozzi, A. (2018) The Immunologic Role of IL-17 in Psoriasis and Psoriatic Arthritis Pathogenesis. Clin Rev Allergy Immunol. 55, 379-390

65 Lowes, M. A., Suarez-Farinas, M. and Krueger, J. G. (2014) Immunology of psoriasis. Annu Rev Immunol. 32, 227-255

66 Hawkes, J. E., Chan, T. C. and Krueger, J. G. (2017) Psoriasis pathogenesis and the development of novel targeted immune therapies. J Allergy Clin Immunol. 140, 645-653

67 Gesser, B., Rasmussen, M. K. and Iversen, L. (2020) Dimethyl Fumarate Targets MSK1, RSK1, 2 and IKKalpha/beta Kinases and Regulates NF-kappaB /p65 Activation in Psoriasis: A Demonstration of the Effect on Peripheral Blood Mononuclear Cells, Drawn from Two Patients with Severe Psoriasis Before and After Treatment with Dimethyl Fumarate. Psoriasis (Auckl). 10, 1-11

68 Yu, X. J., Li, C. Y., Dai, H. Y., Cai, D. X., Wang, K. Y., Xu, Y. H., Chen, L. M. and Zhou, C. L. (2007) Expression and localization of the activated mitogen-activated protein kinase in lesional psoriatic skin. Exp Mol Pathol. 83, 413-418

69 Funding, A. T., Johansen, C., Kragballe, K. and Iversen, L. (2007) Mitogen- and stressactivated protein kinase 2 and cyclic AMP response element binding protein are activated in lesional psoriatic epidermis. J Invest Dermatol. 127, 2012-2019

70 Jin, S. P., Koh, S. J., Yu, D. A., Kim, M. W., Yun, H. T., Lee, D. H., Yoon, H. S., Cho, S. and Park, H. S. (2018) Imiquimod-applied Interleukin-10 deficient mice better reflects severe and persistent psoriasis with systemic inflammatory state. Exp Dermatol. 27, 43-49

71 Wingate, A. D., Martin, K. J., Hunter, C., Carr, J. M., Clacher, C. and Arthur, J. S. (2009) Generation of a conditional CREB Ser133Ala knockin mouse. Genesis. 47, 688-696

72 McGuire, V. A., Ruiz-Zorrilla Diez, T., Emmerich, C. H., Strickson, S., Ritorto, M. S., Sutavani, R. V., Weibeta, A., Houslay, K. F., Knebel, A., Meakin, P. J., Phair, I. R., Ashford, M. L., Trost, M. and Arthur, J. S. (2016) Dimethyl fumarate blocks pro-inflammatory cytokine production via inhibition of TLR induced M1 and K63 ubiquitin chain formation. Sci Rep. 6, 31159 
bioRxiv preprint doi: https://doi.org/10.1101/2020.07.07.189142; this version posted July 7, 2020. The copyright holder for this preprint (which was not certified by peer review) is the author/funder, who has granted bioRxiv a license to display the preprint in perpetuity. It is made
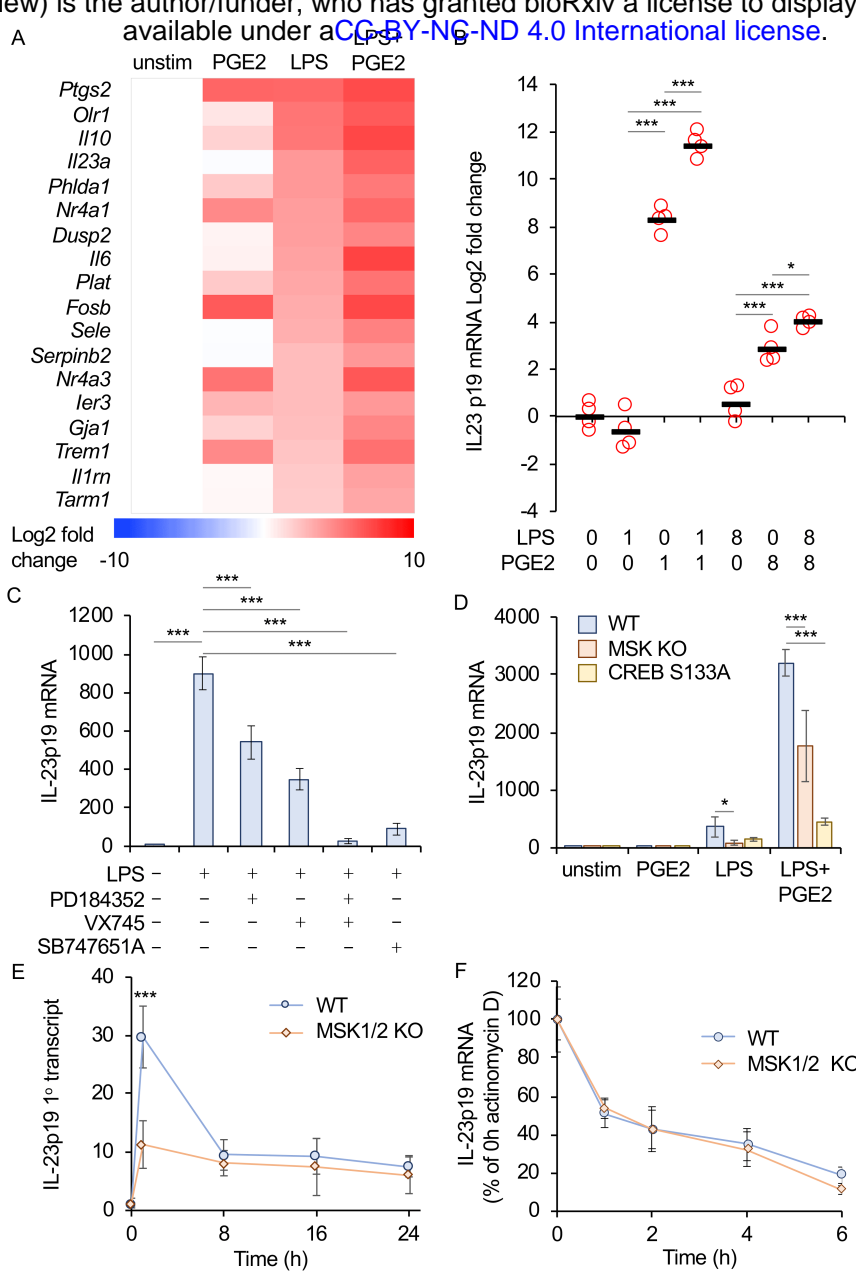

Figure 1. MSK1/2 and CREB regulate IL-12p19 mRNA induction in macrophages.

A) Heat map of genes that were upregulated 4 fold in BMDMs by $100 \mathrm{ng} / \mathrm{ml}$ LPS for $1 \mathrm{~h}$ and a further 2 fold when a combination of LPS and $10 \mu \mathrm{M}$ PGE2 was used.

B) BMDMs were stimulated for 1 or $8 \mathrm{~h}$ with $100 \mathrm{ng} / \mathrm{ml}$ LPS and/or $10 \mu \mathrm{M}$ PGE2 as indicated. Total mRNA was isolated and IL-23p19 mRNA levels determined by qPCR. Bars show average value and circles represent individual values from BMDMs from separate mice. Within time points, a $p<0.05$ is indicated by $*$ and $p<0.001$ by $* * *$ ( 2 way ANOVA and Holm-Sidak post hoc testing).

C) Where indicated BMDMs were treated with $2 \mu \mathrm{M}$ PD184352, $1 \mu \mathrm{M}$ VX745 or $10 \mu \mathrm{M}$ SB747651A before stimulation with $100 \mathrm{ng} / \mathrm{ml}$ LPS for $1 \mathrm{~h}$. IL-23p19 mRNA levels were determined by qPCR.

Compared to the LPS condition, a $p<0.001$ is indicated by $* * *$ ( 1 way ANOVA and Holm-Sidak post hoc testing)

D) BMDMs were isolated form wild type, MSK1/2 knockout and CREB S133A knockin mice. Cells were stimulated for $1 \mathrm{~h}$ with either $10 \mu \mathrm{M}$ PGE2, $100 \mathrm{ng} / \mathrm{ml}$ LPS or a combination of LPS and PGE2. IL-23p19 mRNA levels were measured by qPCR. For comparisons to the wild type stimulations, a $p<0.05$ is indicated by $*$ and $p<0.001$ by $* * *$ ( 2 way ANOVA and Holm-Sidak post hoc testing).

E) Wild type or MSK1/2 knockout BMDMs were stimulated for the indicated times with $100 \mathrm{ng} / \mathrm{ml}$ LPS and IL-23p19 primary transcript levels determined by qPCR. Between genotypes *** indicates $p<0.001$ ( 2 way ANOVA and Holm-Sidak post hoc testing).

F) Wild type or MSK1/2 knockout BMDMs were stimulated for $1 \mathrm{~h}$ with $100 \mathrm{ng} / \mathrm{ml}$ LPS before addition of $1 \mu \mathrm{g} / \mathrm{ml}$ actinomycin D. IL-23p19 mRNA levels were determined at $0,1,2,4$ and $6 \mathrm{~h}$ after actinomycin D addition. Wild type and MSK1/2 knockouts were not significantly different (2 way ANOVA).

In B-E mRNA levels are expressed as fold induction relative to unstimulated wild type cells. In $\mathrm{C}$ to $\mathrm{F}$, graphs show the average and standard deviations of independent cultures from 4 mice per genotype. 


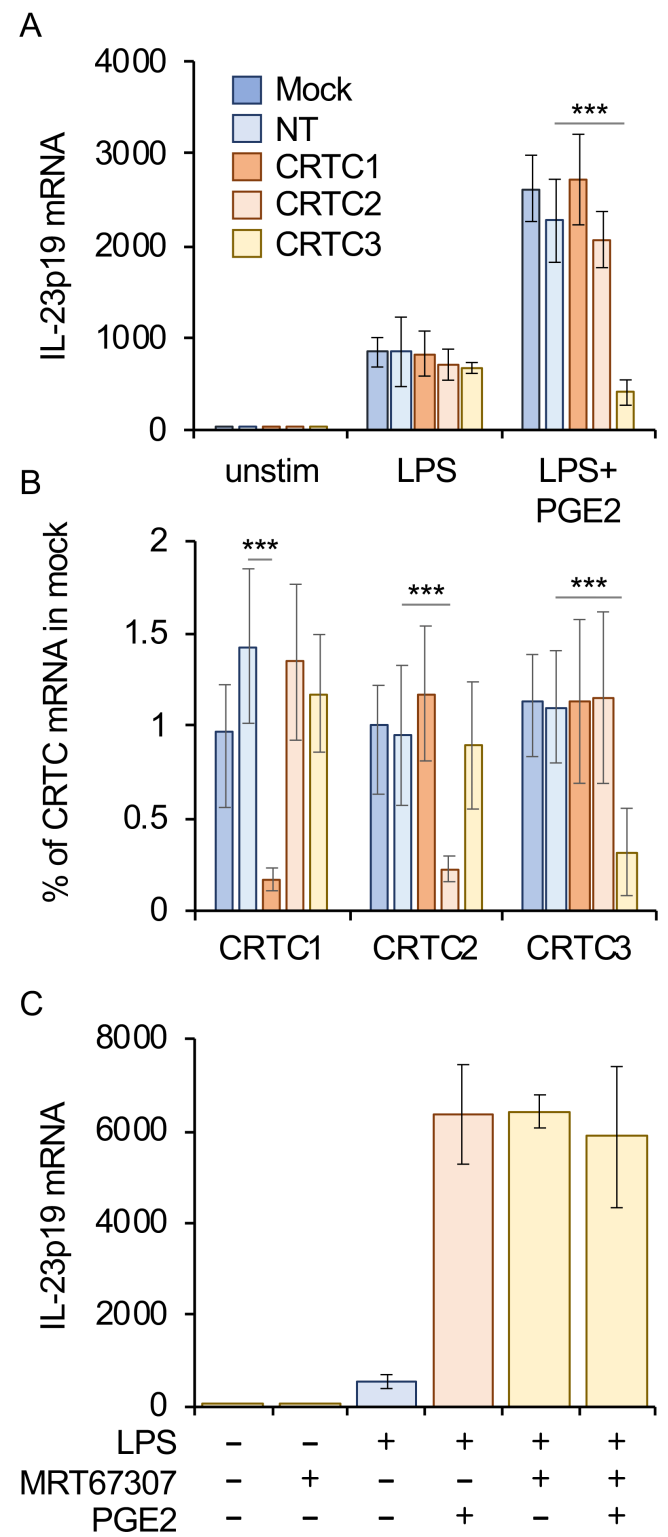

Figure 2. PGE2 promotes IL-23p19 mRNA induction via CRTC3.

A) Wild-type BMDMs were transfected with siRNA against CRTC1, 2, or 3, a nontargeting siRNA control (NT) or no siRNA (mock). Twenty-four to 48 hours after transfection cells were stimulated with either $100 \mathrm{ng} / \mathrm{ml}$ LPS or LPS and $10 \mu \mathrm{M} \mathrm{PGE}_{2}$ for $1 \mathrm{~h}$, and the levels of IL-23p19 mRNA were determined by qPCR.

B) As (A) but mRNA levels for CRTC1, CRTC2 and CRTC3 were determined. Values for the unstimulated conditions are shown but similar results were obtained for the $1 \mathrm{~h}$ time point.

C) Where indicated wild type BMDMs were incubated for $1 \mathrm{~h}$ with $2 \mu \mathrm{M}$ MRT67307 before stimulation with 100ng/ml LPS and/or $10 \mu \mathrm{M}$ PGE2 for a further hour. IL-23p19 mRNA levels were then determined by qPCR.

Graphs show the average and standard deviation of culture from 4 mice. In $\mathrm{A}$ and $\mathrm{B}$, for comparisons to the non-targeting siRNA, a $p<0.001$ is indicated by $* * *$ ( 2 way ANOVA and Holm-Sidak post hoc testing). 
bioRxiv preprint doi: https://doi.org/10.1101/2020.07.07.189142; this version posted July 7, 2020. The copyright holder for this preprint (which was not certified by peer review) is the author/funder, who has granted bioRxiv a license to display the preprint in perpetuity. It is made
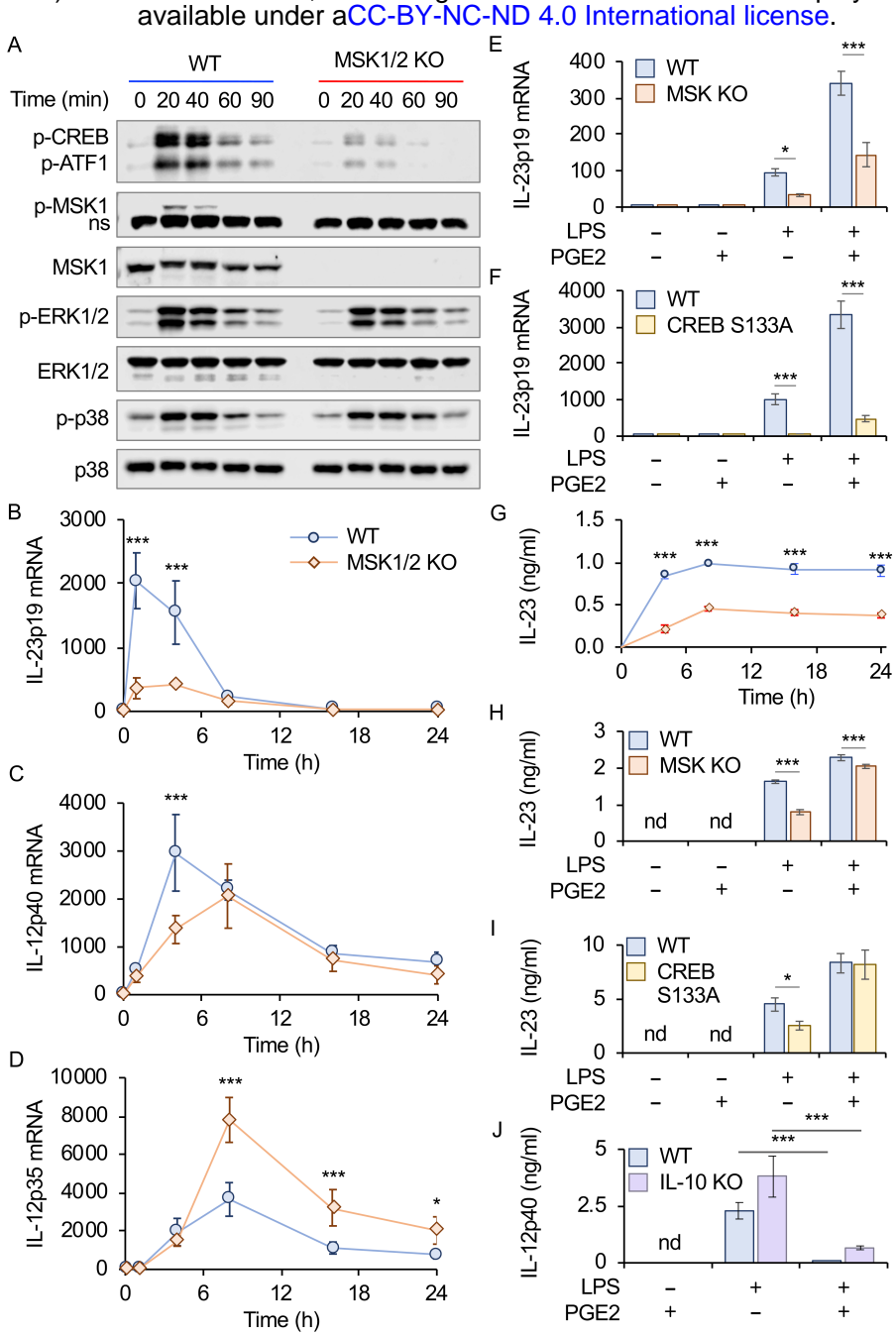

Figure 3. Regulation of IL-23 production by MSK1/2 and CREB in GM-BMCs.

A) Wild type or MSK1/2 knockout GM-BMCs were stimulated for the indicated times with 100 $\mathrm{ng} / \mathrm{ml}$ LPS and the levels of the indicated phospho and total proteins determined by immunoblotting. ns indicates a non-specific band.

B-D) Wild type or MSK1/2 knockout GM-BMCs were stimulated for the indicated times with 100 $\mathrm{ng} / \mathrm{ml}$ LPS and the levels of IL-23p19 (B), IL-12p40 (C) and IL-12p35 (D) determined by qPCR.

E) Wild type or MSK1/2 knockout GM-BMCs were stimulated for $1 \mathrm{~h}$ with $100 \mathrm{ng} / \mathrm{ml} \mathrm{LPS}$ and/or 10 $\mu \mathrm{M}$ PGE2 as indicated and IL-23p19 mRNA levels determined.

F) Wild type or CREB S133A knockin GM-BMCs were stimulated for $1 \mathrm{~h}$ with $100 \mathrm{ng} / \mathrm{ml} \mathrm{LPS}$ and/or $10 \mu \mathrm{M}$ PGE2 as indicated and IL-23p19 mRNA levels determined.

G) Wild type or MSK1/2 knockout GM-BMCs were stimulated for the indicated times with 100 $\mathrm{ng} / \mathrm{ml}$ LPS and the level of IL-23 secreted determined by ELISA.

H) Wild type or MSK1/2 knockout GM-BMCs were stimulated for $8 \mathrm{~h}$ with $100 \mathrm{ng} / \mathrm{ml} \mathrm{LPS}$ and/or 10 $\mu \mathrm{M}$ PGE2 as indicated and the level of IL-23 secreted determined by ELISA.

I) Wild type or MSK1/2 knockout GM-BMCs were stimulated for $8 \mathrm{~h}$ with $100 \mathrm{ng} / \mathrm{ml} \mathrm{LPS}$ and/or 10 $\mu \mathrm{M}$ PGE2 as indicated and the level of IL-23 secreted determined by Luminex assay.

J) Wild type or IL-10 knockout GM-BMCs were stimulated with $100 \mathrm{ng} / \mathrm{ml}$ LPS or LPS and $10 \mu \mathrm{M}$ PGE2 for $8 \mathrm{~h}$ and IL-12p40 secretion measured by a Luminex based assay.

In $\mathrm{B}$ to $\mathrm{J}$ data represent average and standard deviation from BMDMs from 4 mice per genotype. nd indicates conditions were the level of cytokine was below what could be detected in the assay. In $\mathrm{B}$ to I, for comparisons between wild type and MSK1/2 a $<<0.001$ in shown by *** (B-D 1 way ANOVA, E-I 2 way ANOVA with Holm-Sidak post hoc testing). In J a difference between the LPS and LPS + PGE2 condition with a $\mathrm{p}<0.001$ (Students ttest) in indicated by $* * *$. 


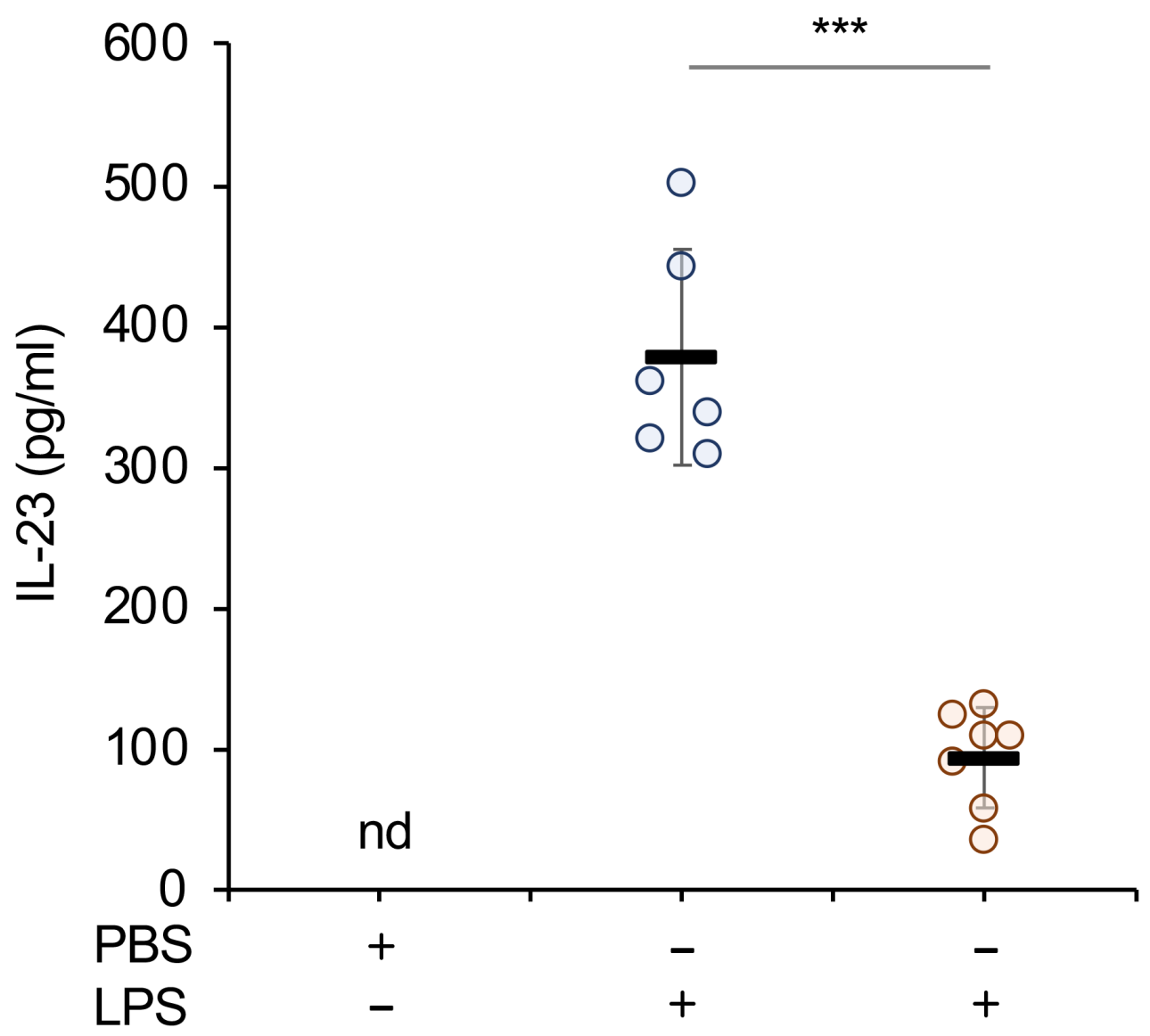

Figure 4. MSK1/2 regulate IL-23 induction following i.p. injection of LPS.

Wild type or MSK1/2 knockout mice were given an i.p. injection of either LPS $(2 \mathrm{mg} / \mathrm{kg})$ or PBS vehicle as indicated. After $4 \mathrm{~h}$ serum levels of IL-23 were measured by ELISA. Bars show average and standard deviation with measurements from individual animals shown by circles. Relative to wild type LPS injected mice a $p$ value (two tailed Students ttest) of $<0.001$ is shown by $* * *$. 
bioRxiv preprint doi: https://doi.org/10.1101/2020.07.07.189142; this version posted July 7, 2020. The copyright holder for this preprint (which was not certified by peer review) is the author/funder, who has granted bioRxiv a license to display the preprint in perpetuity. It is made

A available under aCC-BY-NC-ND 4.0 International license.
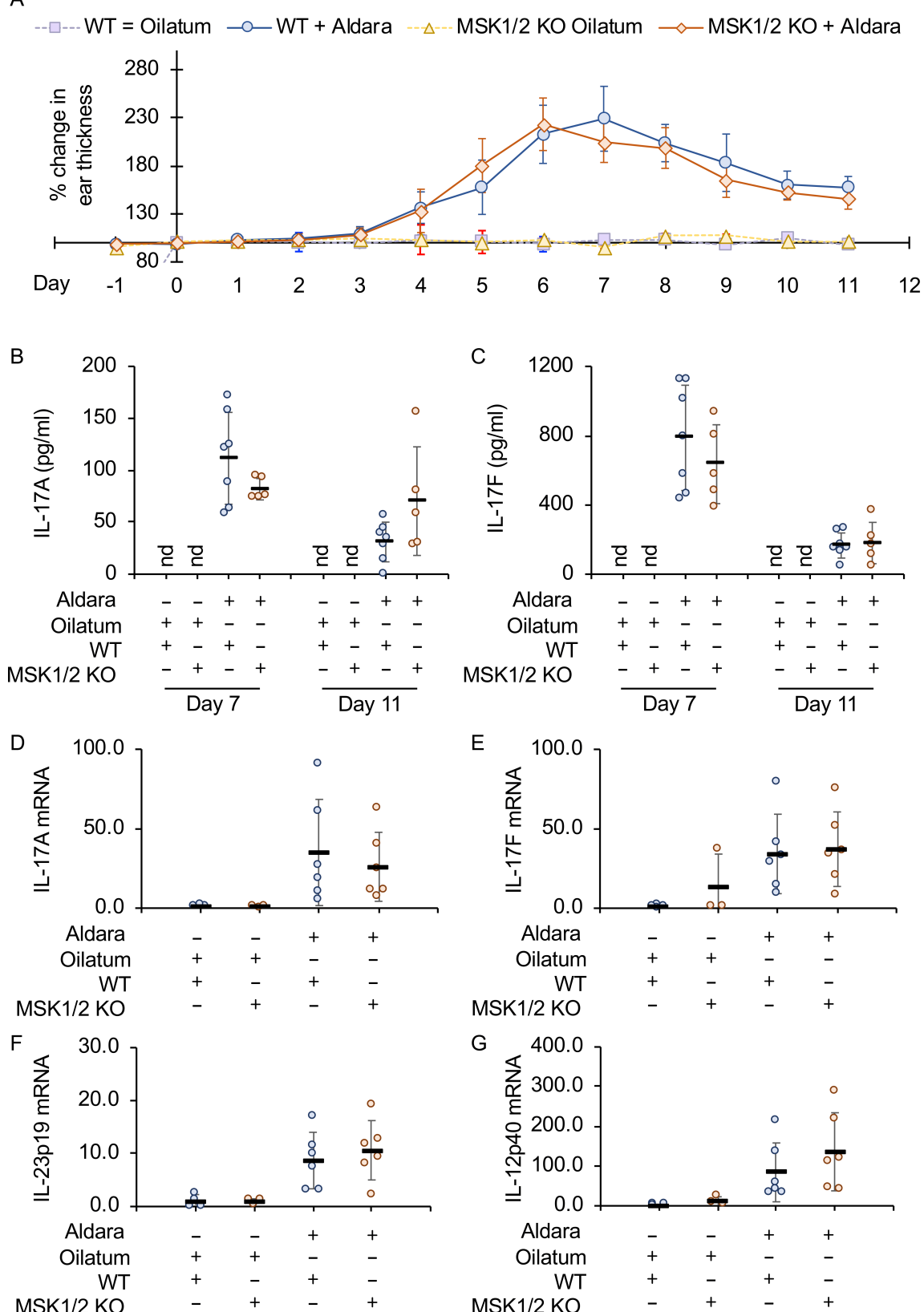

Figure 5. Imiquimod induced skin inflammation in MSK1/2 knockout mice.

A-C) Wild type or MSK1/2 knockout mice were treated daily from day 1 to 7 with either Aldara or Oilatum cream as described in the methods (WT Oilatum n=5, MSK1/2 KO Oliatum n=2, Wild type Aldara $n=7$, MSK1/2 KO Aldara $n=5$ ). Ear thickness is shown in (A) and IL-17A levels in ear biopsies in (B) and IL-17F levels in (C).

D-G) Wild type or MSK1/2 knockout mice were treated daily with Aldara or Oilatum cream for 6 days (WT Oilatum $n=4$, MSK1/2 KO Oliatum n=3, Wild type Aldara $n=6$, MSK1/2 KO Aldara $n=6$ ). RNA was then isolated from the ear and levels of IL-17A (D), IL-17F (E), IL-23p19 (F) and IL-12p40 (G) mRNA determined. Values show fold change relative to the average values of wild type Oilatum treated mice. Graphs show mean and standard deviation with individual mice in B to F shown by circles. No effect of genotype was observed ( $p>0.05,3$ way ANOVA for A, two tailed students ttest for B-G), 
bioRxiv preprint doi: https://doi.org/10.1101/2020.07.07.189142; this version posted July 7, 2020. The copyright holder for this preprint (which was not certified by peer review) is the author/funder, who has granted bioRxiv a license to display the preprint in perpetuity. It is made

A

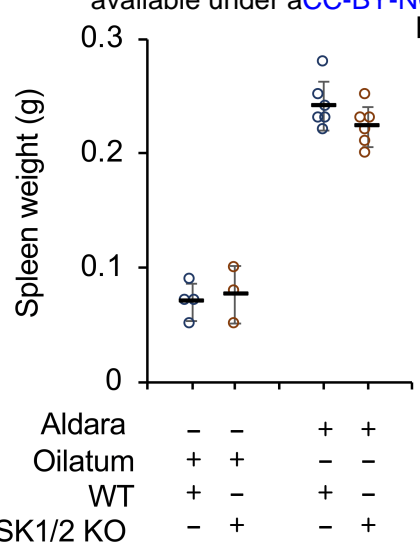

$\mathrm{B}$

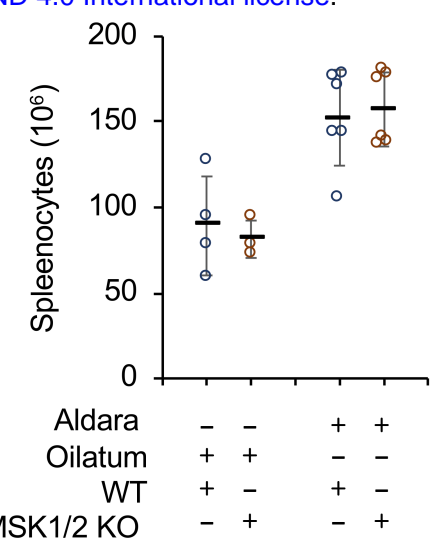

C

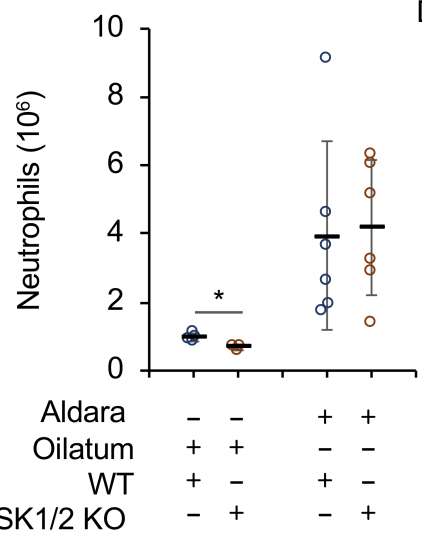

$\mathrm{D}$

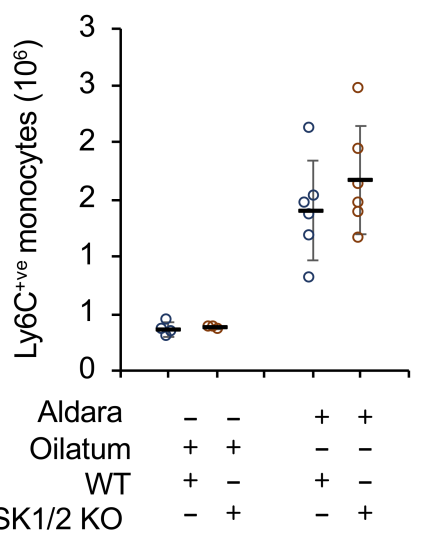

E

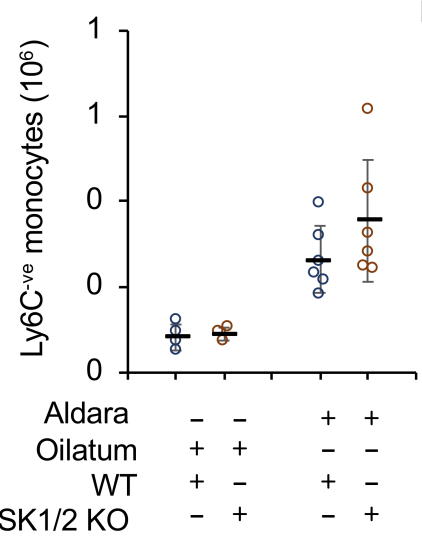

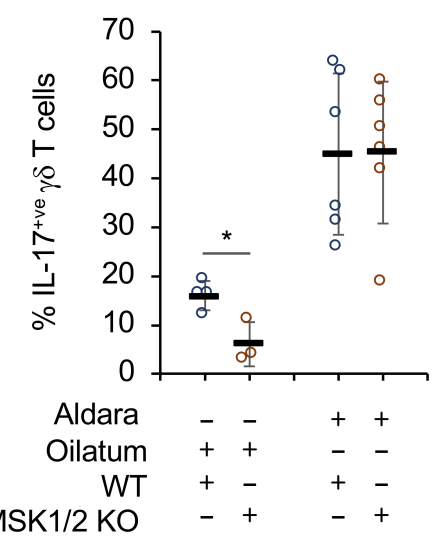

Figure 6. Effect of imiquimod on myeloid cells and $\gamma \delta \mathrm{T}$ cells.

Wild type or MSK1/2 knockout mice were treated daily with Aldara or Oilatum cream for 6 days (WT Oilatum n=4, MSK1/2 KO Oliatum n=3, Wild type Aldara $n=6$, MSK1/2 KO Aldara n=6). Spleens were isolated and analysed by flow cytometry as described in the methods. Graphs show spleen weight (A), total number of splenocytes following lysis of red blood cells (B), numbers of neutrophils (C), Ly6C $\mathrm{C}^{+\mathrm{ve}}$ monocytes (D), Ly6 $\mathrm{C}^{-\mathrm{ve}}$ monocytes (E). In (F), cells were stimulated with ionomycin and PMA and the percentage of $\gamma \delta$ T cells expressing IL-17 quantified by flow cytometry as described in the methods. Graphs show mean and standard deviation with individual mice in B to F shown by circles. Between wild type and MSK1/2 knockouts, a $p<0.05$ in indicated by * (two tailed Students ttest). 
bioRxiv preprint doi: https://doi.org/10.1101/2020.07.07.189142; this version posted July 7, 2020. The copyright holder for this preprint (which was not certified by peer review) is the author/funder, who has granted bioRxiv a license to display the preprint in perpetuity. It is made

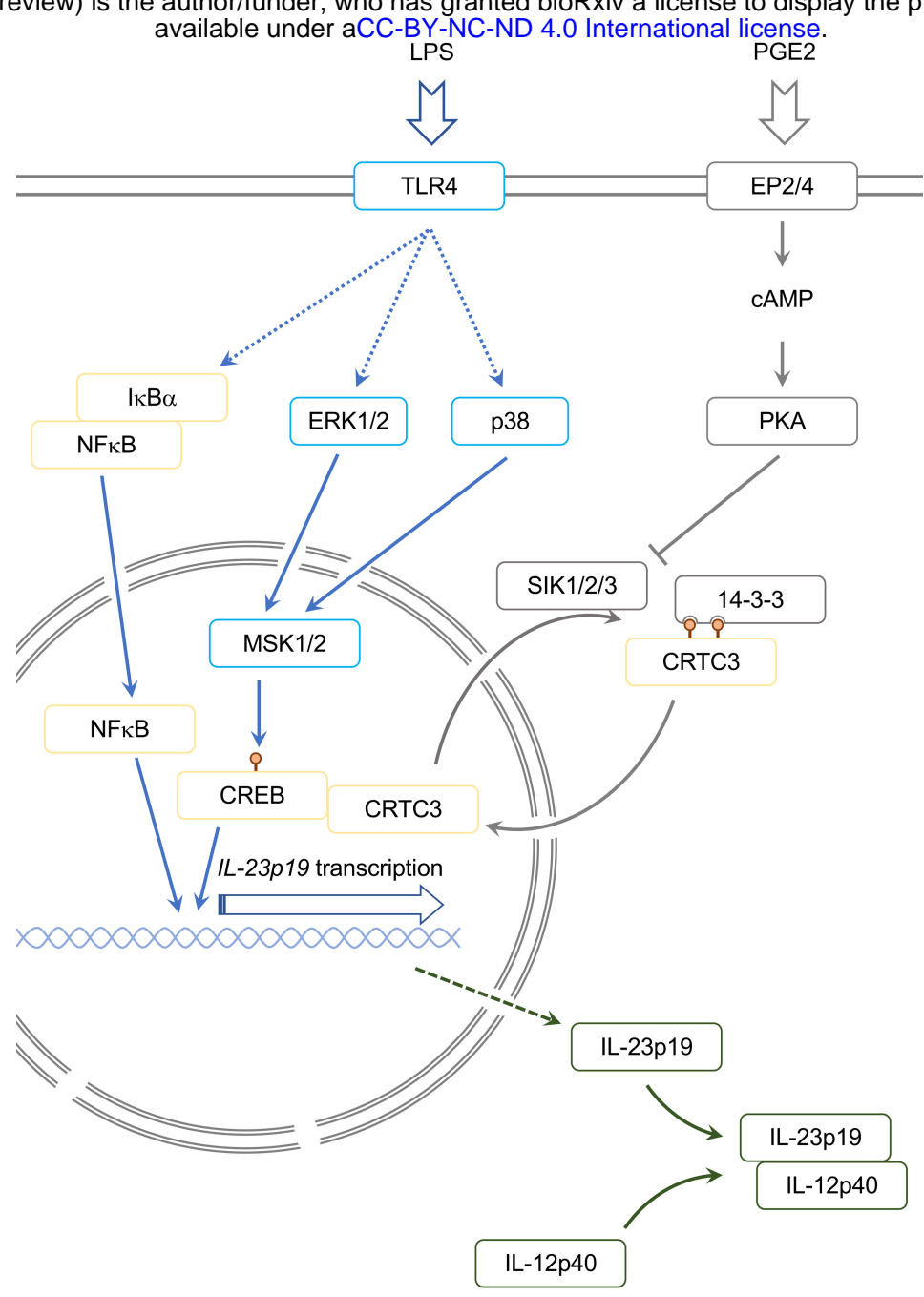

Figure 7. Model for control of IL-23p19 induction.

LPS acts via TLR4 to stimulate the activation of the ERK1/2 and p38 MAPK pathways, leading to the activation of MSK1 and 2. MSKs then phosphorylate CREB on Ser133 on the IL-23p19 promoter, leading to the activation of IL-23p19 transcription. CREB phosphorylation alone is insufficient to activate the IL-23p19 promoter, in addition TLR4 activation results in the degradation of IкB $\alpha$

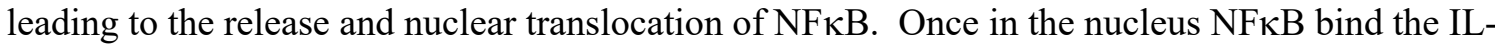
23p19 promoter and in combination with CREB S133 phosphorylation this results in IL-23p19 transcription.

CRTC3 can act as a co-activator for CREB. In the absence of stimulation CRTC3 is phosphorylated by one or more of the SIK isoforms. This creates a binding site for 14-3-3 proteins and the retention of CRTC3 in the cytoplasm. PGE2 acts via the EP2 and ER4 receptors to stimulate the production of cAMP which activates PKA. PKA then phosphorylates SIKs which inhibits the ability of SIKS to phosphorylate CRTC3 in the cells. This allows CRTC3 dephosphorylation, resulting in its translocation to the nucleus where it acts as a CREB co-activator at the IL-23p19 promoter. Once transcribed, IL-23p19 protein heterodimerises with IL-12p40 to form IL-23 which can then be secreted from the cell. 